Bangladesh J. Plant Taxon. 13(2): 93-109, 2006 (December)

\title{
TAXONOMIC REVISION OF THE GENUS CAESALPINIA L. (CAESALPINIACEAE) FOR BANGLADESH
}

\author{
B.M. Rezia Khatun ${ }^{1}$ and MoHammad Oliur Rahman \\ Bangladesh National Herbarium, Chiriakhana Road, Mirpur-1 \\ Dhaka-1216, Bangladesh
}

Key words: Caesalpinia, Taxonomic revision, Caesalpiniaceae, Bangladesh

\begin{abstract}
The genus Caesalpinia L. represented by 12 species has been revised for Bangladesh. Dichotomous bracket key has been given for identification of the species. An updated nomenclature, description of the taxa along with illustrations, specimens examined, ecology, notes on distribution and economic importance have been provided. Chromosome number and ethnobotanical information have also been furnished in most cases.
\end{abstract}

\section{Introduction}

The genus Caesalpinia L. (Caesalpiniaceae) is a pantropical genus of trees, shrubs and prickly climbers comprising of about 150 species distributed throughout the world (Verdcourt 1979). Most of the members of Caesalpinia are economically, medicinally and horticulturally important. Caesalpinia pulcherrima is a popular ornamental plant, equally important for medicine to treat different bronchial diseases including asthma and bronchitis and cholera, diarrhoea, dysentery and liver complaints (Ghani 2002). Caesalpinia bonduc is used as a native medicine in India to relieve colic, fever, hydrocele, diarrhoea and rheumatism (Bor and Raizada 1954). Some species of this genus produce important tannin and dye viz., C. coriaria, C. digyna, C. decapetala and C. sappan (Ali 1973).

There has been no taxonomic revision of this important genus in Bangladesh although the genus received much attention in India and Pakistan. Sanjappa (1992) recorded 20 species of Caesalpinia including both wild and cultivated species from India, whereas, Ali (1973) reported only six species from Pakistan. Earlier, Baker (1878) reported 10 species from Indian sub-continent while Prain (1903) recorded six species from the present territory of Bangladesh. A thorough and critical study of a large number of specimens from Bangladesh and detailed literature survey (Heinig 1925, Datta and Mitra 1953, Sinclair 1955, Khan et al. 1996) revealed that the following 12 species of the genus are present in Bangladesh, viz., Caesalpinia bonduc, C. cacalaco, C. coriaria, C. crista, C. cuculata, C. decapetala, C. digyna, C. enneaphylla, C. hymenocarpa, C. pulcherrima, C. sappan and C. tortuosa. The updated nomenclature, important synonyms, detailed taxonomic account, ecology, specimens examined, economic value and worldwide distribution have been furnished under each taxon. A key to species has

\footnotetext{
${ }^{1}$ Corresponding author.
} 
also been given. Chromosome number and ethnobotanical information have been provided wherever available. Illustrations for rare and uncommon species have been given.

Caesalpinia L. Sp. Pl. 380: (1753)

Trees, shrubs or woody scandent, prickly climbers, rarely unarmed. Stipules present or not, minute to foliaceous, deciduous or persistent. Leaves alternate, bipinnately compound, rachis armed with prickles below the insertion of pinnae and pinnula; leaflets opposite and rarely alternate. Flowers zygomorphic, bisexual or sometimes unisexual, stalked, yellow, red, showy. Inflorescence of axillary to terminal or supra-axillary, panicled racemes. Bracts mostly deciduous, bracteoles absent. Hypanthium usually obliquely short-cupular or funnel shaped. Sepals 5, free or connate at the base, unequal, imbricate or valvate, the lowest one largest and cucullate, clasping the others, often reflexed during anthesis. Petals 5, free, unequal, spathulate, spreading, usually orbicular with a distinct claw, the standard petal differing in shape and size with a liguliform appendage. Stamens 10, free, delicate; filaments hairy; anthers oblong, uniform, versatile, dorsifixed, split longitudinally. Ovary sessile to sub-sessile; style filliform; stigma terminal, oblique. Pods very variable, oblong, ligulate, thin and flat or thick and subturgid, smooth or spiny. Seeds orbicular to oblong, globose or flat, usually exalbuminous.

\section{Key to species}

1. Leaflets stalked, stalk more than $0.5 \mathrm{~mm}$; pod winged or wingless, when wingless neither swollen on each seed, nor the sutures thickened

- $\quad$ Leaflets sessile or sub-sessile, stalk if present less than $0.5 \mathrm{~mm}$; pod wingless but thickened along the suture

2. Pedicels and stamens more than $5 \mathrm{~cm}$ long; leaflets with stipels. Flowers dark red, yellow or orange-yellow

- $\quad$ Pedicels and stamens less than $3 \mathrm{~cm}$ long; leaflets without stipels

C. pulcherrima

3. Racemes up to $6 \mathrm{~cm}$ long; leaflets up to $2.5 \mathrm{~mm}$ wide. Pod flexuous, twisted

- $\quad$ Racemes more than $10 \mathrm{~cm}$ long; leaflets more than $3 \mathrm{~mm}$ wide

4. Leaflets obovate, retuse; pods cylindrical, transversely clefted

Leaflets not obovate; pods neither cylindrical nor transversely clefted

5. Pods armed with numerous spines, dehiscent. Stipules pinnate, foliaceous

- $\quad$ Pods unarmed, indehiscent

6. Leaflets 2-3 pairs; pod rhombic-elliptic, woody

- $\quad$ Leaflets more than 3 pairs; pod oblong, not woody

7. Standard about as large as the other petals, butterfly-shaped; pod 1-seeded

- $\quad$ Standard rounded at the top; pod more than 1-seeded

8. Ovary hairy. Ovules 8-10. Wing in pod sharply beaked

- $\quad$ Ovary glabrous

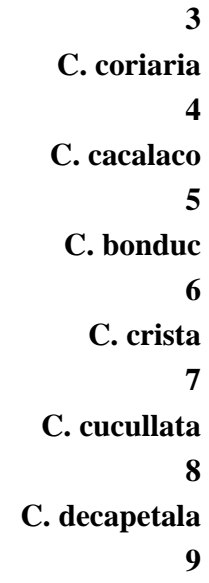


9. Flower buds glabrous; wing of the pod 4-6 mm wide

- $\quad$ Flower buds hairy; wing of the pod 7-12 mm wide

10. Pedicels jointed near the top; ovary hairy; pod with dorsal suture ending in a sharp beak

- $\quad$ Pedicels not jointed near the top; ovary usually glabrous; pod swollen on each side, indehiscent

11

11. Leaf rachis up to $23 \mathrm{~cm}$ long; leaflets membranous, loosely arranged, hairy, dull above

- Leaf rachis $30 \mathrm{~cm}$ or longer; leaflets glabrous or very short-hairy, chartaceous, closely arranged, shining above

C. tortuosa

1. Caesalpinia bonduc (L.) Roxb., Fl. Ind. ed. 2 (2) : 362 (1832). Brandis, Ind. Trees: 246 (1906). Guilandina bonduc L., Sp. Pl. : 381 (1753); C. bonducella (L.) Fleming, Baker in Hook f., Fl. Brit. Ind. 2 : 254 (1878); Prain, Beng. Pl. 2 : 449 (1903).

Local names: Nata, Natai, Jhagragota, Lalkanta, Touri; English name: Fever nut

A vigorous climber or scrambling bushy shrub or small tree up to $5 \mathrm{~m}$ high, armed with numerous hairy prickles. Leaves compound, paripinnate, stipulate. Rachis $30-80 \mathrm{~cm}$ long; pinnae 3-9 (-11) pairs, c 8-20 cm long; leaflets 7-12 pairs, c 2-4 × 1-2 cm, ovateoblong to elliptic-lanceolate, obtuse to sub-acute at apex, rounded and unequal at base. Inflorescence supra-axillary, simple or panicled racemes, dense at the top. Flowers yellow, c $1 \mathrm{~cm}$ long, articulated, bracts linear-oblong, cuspidate, c 6-12 mm long, pedicels 4-6 mm long, pubescent. Sepals 5, subequal, c 5-8 × 2-3 mm, rusty tomentose. Petals 5, golden yellow, the standard petal with red spotted or patches, c 4-4 $\times 3-4 \mathrm{~mm}$ with claw c 3-4 × 1-2 mm, reflexed, other 4 petals spathulate, c 8-10 × 3-4 mm. Stamens 10; filaments 6-10 mm long, anthers c $1 \mathrm{~mm}$ long. Ovary seated on a short gynophore, developed from the base of the calyx tube; style 3-4 mm long; stigma ciliate. Fruit a pod, c 6.0-9.0 $\times$ 3.5-4.5 cm, oblong, covered with sharp wiry prickles, dehiscent. Seeds one or two, c 1.5-2.0 cm across. Flowering and fruiting : July - April.

Chromosome number : $2 \mathrm{n}=24$ (Atchison 1951).

Ecology : Grows in coastal areas, inland in scrub jungle, hedges of the crop fields, roadsides, ditches and sometimes forming thickets on vacant lots as ruderal habitat.

Specimens examined: Bagerhat : Bagerhat, 12.6.1974, Khan \& Huq, K 3950; Mongla, 28.6.1986, Huq \& Mia, H 7797. Chittagong : Moheskhali, 31.8.81, Mia, Huq \& Rahman, M 667. Cox's Bazar : St Martin's Island, Dhulipara, near jangle, 27.10.1996, M.S. Khan, K 9676. Dhaka : Badyrbazar, 3.10.1977, Huq \& Rahman, H 3508. Faridpur: Pansa, 3.11.1974, Nashiruddin Talukder No. 28. Gazipur : Kaliganj to Ghorashal, 6.9.1986, M.K. Mia, M 1251. Jessore : Kaligang Katchandpur, 1.9.1983, Huq, Mia \& Mahbuba, H 6125. Mymensingh: Bangladesh Agricultural University campus, 19.9.1980, Mia, Huq \& Rahman, M 397. Rajshahi : Near Padma river, 
12.12.1972, A.M. Huq, H 636. Thakurgoan : Birganj beat, 14.4.1996, Khan \& Rashid, K 9479.

Economic importance: The nuts and root bark are considered to be tonic, antiperiodic and febrifuge. The leaves and seeds are much used as native medicine to relieve colic, fever, hydrocele, diarrhoea and rheumatism. The seeds are also used as an anthelmintic, vermifuge, chewed for coughs and eaten for stomach trouble as well as for curing gout (Kanjilal et al. 1938, Bor and Raizada 1954).

Ethnobotanical information: The villagers use this plant as an effective hedge plant to protect the crop fields in the northern districts of Bangladesh. The leaves are used as emmenagogue in Indo-China (Caius 1989). Powered seeds are administered to cure malarial fever and also used as anthelmintic in Sundarbans region of India (Tribedi et al. 1993).

Distribution: China, Hong Kong, India, Nepal, Malay Peninsula, Myanmar, the Philippines, Sri Lanka, Taiwan and New Guinea.

2. Caesalpinia cacalaco Humb. ex Bonpl., Pl. Aeqninoct, 2: 173, t. 137 (1809); Sen \& Nasker, Bull. Bot. Surv. Ind. 7: 36 (1965); Sanjappa, Legumes of Ind.: 13 (1992).

(Plate 1)

An unarmed, low spreading shrubby tree of about 4-5 $\mathrm{m}$ high. Leaves compound, bipinnate. Rachis 3.5-12.0 cm long; pinnae 3-6 pairs, c 2.0-5.5 cm long; leaflets 3-5 pairs, c 1.0-2.2 × 0.6-1.5 cm, obovate, often retuse, puberulent, pale beneath. Inflorescence of large terminal panicles, с 20-32 cm long. Flowers $1.5 \mathrm{~cm}$ across, pedicels $1.0-1.5 \mathrm{~cm}$ long, jointed about $0.5 \mathrm{~cm}$ apart from the base of calyx, flower buds subtended by bract, c 7-10 × 1-2 mm, linear oblong, cuspidate. Calyx sub-campanulate, sepals 5, lower sepals hooded, clasping the others, greenish, golden brown pubescent. Petals 5, yellow or orange, stripped with red. Stamens 10, free; filaments flattened near the base, reddish or grey, bearded at lower half; anthers ovate, purple or brown. Pods cylindrical, c $15 \mathrm{~cm}$ long, many seeded. Seeds separated by equal number of constriction in the wall of the pods. Flowering and fruiting : January - August.

Ecology: In plains, sunny and dry areas.

Specimens examined: Dhaka : Dhaka University, S.M. Hall Compound, 26.1.1990, Momtaz Begum 168 (B); S.M. Hall Compound, 10.2.1954, Md. Shajahan, No. sn; S.M. Hall, 5.1.1956, M. Rahman 39.

Distribution: Native of South America; introduced in many parts of the world as an ornamental plant. This is rarely cultivated in Bangladesh.

Economic importance: This species is used as an ornamental plant for its delicate foliage and profusely display of yellow flowers. 


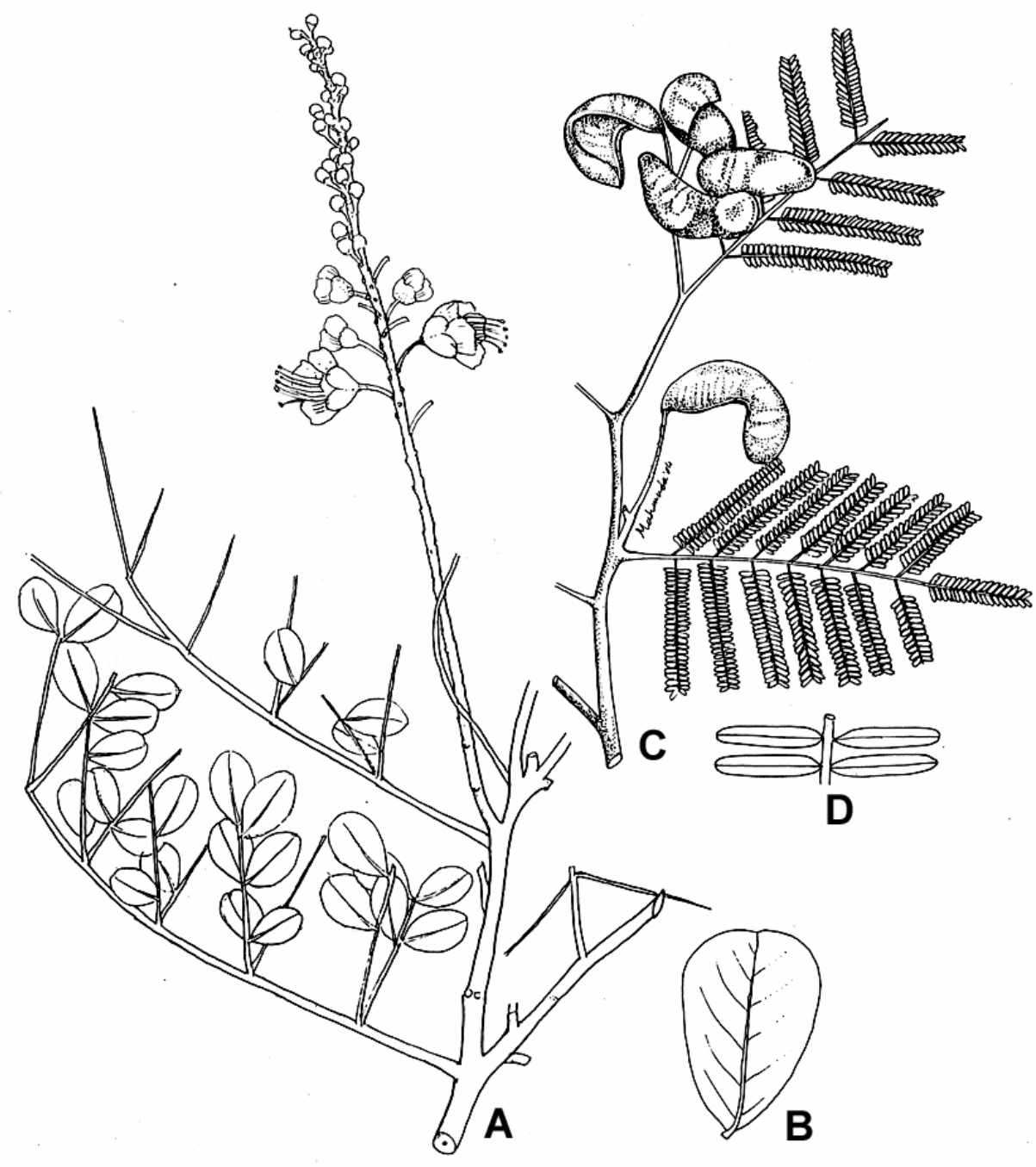

Plate 1. Caesalpinia cacalaco (A-B): A. flowering shoot $(\times 0.5)$; B. leaflet $(\times 2)$. Caesalpinia coriaria (C-D): C. part of branch with pods $(\times 0.33)$; D. part of pinna with leaflets $(\times 2.67)$.

3. Caesalpinia coriaria (Jacq.) Willd., Sp. Pl. ed. 4, 2: 532 (1799); Backer \& Bakh. f., Fl. Java 1 : 544 (1964); Hattink, Reinwardtia 15: (1974); Ali, Fl. Pak. 54: 35 (1973); Verdc., Manual New Guinea Leg. Bot. Bull. 11 : 23 (1979); Vidal, Fl. Camb. Laos \& Vietnam 18: 23 (1980); Lock, Leg. Africa: 20 (1989); Kumar \& Sane, Leg. Asia : 28 (2003); Poinciana coriaria Jack., Select. Strip. Amer. Hist.: t.175, f. 36 (1735).

Local name: Umulkuchi; English name: American Sumac

(Plate 1) 
An unarmed, glabrous, large scandent shrub to small deciduous tree up to $10 \mathrm{~m}$ high. Leaves bipinnate, compound. Rachis 10-20 cm long; pinnae 3-9 pairs, 5-8 cm long; leaflets 20-30 pairs, c 5-9 × 1-2 mm, linear-elliptic to oblong, sessile to sub-sessile, opposite or sub-opposite, slightly obliquely sub-cordate at base, rounded to truncate or emarginate at apex, pubescent to glabrous, dark green above and greyish beneath. Inflorescence of supra-axillary to terminal, dense panicles up to $5 \mathrm{~cm}$ long, much shorter than the subtending leaves. Flowers greenish yellow, sweet scented, almost sessile. Calyx tube c 1-2 mm long, sepals 5, equal or rarely subequal, c 7-9 $\times 3-4 \mathrm{~mm}$, ovate. Corolla c 5 $\mathrm{mm}$ long, petals 5, standard petal c 4-6 × 3-4 mm with 3-4 × 1-2 mm claw, yellow. Stamens 10; filaments free; anthers versatile. Ovary stipitate, glabrous; style short. Pods asymmetric, ovate-oblong, inflated, turgid, valves blackish brown, c 3.0-5.0 $\times 0.8-1.0 \mathrm{~cm}$, thick and pulpy within. Seeds flat, rounded. Flowering and fruiting : September - March.

Chromosome number: 2n = 24 (Bir and Kumari 1980).

Ecology: Sunny and dry places up to $700 \mathrm{~m}$ elevation and even in poor soil.

Specimens examined: Sylhet : Sylhet, 12.10.1973, Khan, Huq \& Hassan, K 3237; Tilagarh, M.C. College Campus, 6.1.1978, Huq \& Rahman, H 3676; M.C. College Campus, 22.10.1986, Huq \& Mia, H 7941.

Economic importance: It is suitable for planting in small avenue and large parks due to its dark green foliage with umbrella shaped-canopy for shade and brilliant greenish yellow, scented flowers. This is important for chemical products, medicine and timber (Kumar and Sane 2003). The timber is hard and very heavy. The barks and the pods are considered as astringent.

Ethnobotanical information: In India, the bark is applied for treatment of chronic fever and the decoction of powdered pods are used for washing the bleeding piles. In Southern part of India the pod is used as a source of powerful tanning, which is used to make ink. In Mexico, a black dye is extracted (Bor and Raizada 1954, Caius 1989).

Distribution: Native of tropical America. Frequently found in India, Taiwan and West Indies.

4. Caesalpinia crista L., Sp. Pl. 1 : 380 (1753), pro parte, emend. Dandy \& Exell, J. Bot. 76 : 179 (1938). Hattink, Reinwardtia 9 : 20 (1974); Huang, Fl. Taiwan 3 : 185 (1977); C. chinensis Roxb., Fl. Ind. ed. 2, 2 (1832). Guilandia nuga L., Sp. Pl. ed. 2 : 546 (1762).

(Plate 2)

Local name: Letkanta

A glabrous, scandent, prickly shrub or small tree. Leaves bipinnate, compound, c 15$25 \mathrm{~cm}$ long, stipulate, stipule caducous. Rachis c 10-30 cm long including petiole, armed with short, hooked or recurved spine beneath; pinnae 6-8 pairs; leaflets 2-3 (-5) pairs, c 2$6 \times 1.5-3.0 \mathrm{~cm}$, ovate-elliptic to lanceolate-ovate, obtuse to shortly acute at the apex. 
Inflorescence axillary to terminal panicle, c $20-40 \mathrm{~cm}$ long with many flowers. Bracts c 1 $\mathrm{mm}$ long, caducous. Flowers yellow, fragrant, pedicels 1.0-1.5 cm long. Calyx broadly obconic, glabrous, 10 ribbed, sepals 5, oblong, c 6-8 × 2-4 mm. Petals 5, yellow, the standard petal deep orange or red striped, hairy inside towards the middle, claw c $5 \mathrm{~mm}$ long, other petals c 8-10 × 3-4 mm, orbicular. Stamens 10; filaments woolly; anthers orange. Ovary shortly stalked, seated on oblique gynophore,; style c $8 \mathrm{~mm}$ long; stigma ciliate. Pods rhombic-elliptic in outline, c 4.0-7.0 $\times$ 2.5-3.5 cm, indehiscent, turned blackish when dry. Seeds 1 or 2 per pod, rounded to ovate or kidney shaped. Flowering and fruiting : August - May.

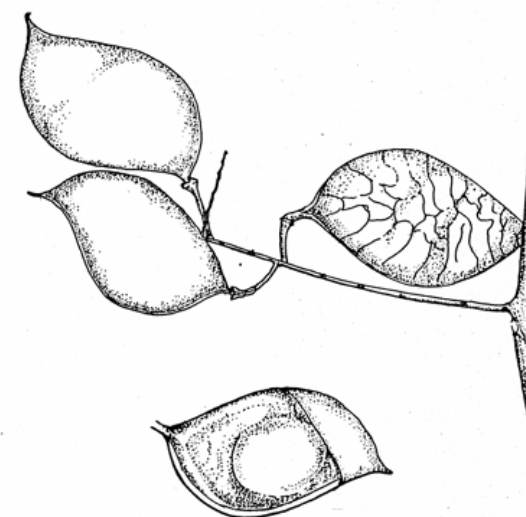

B

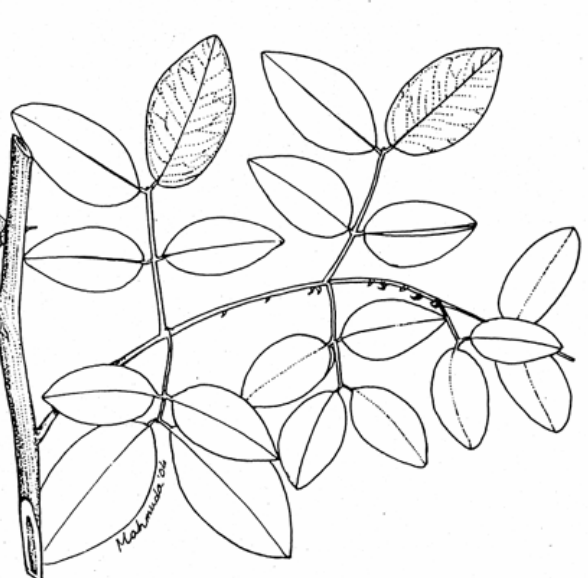

A
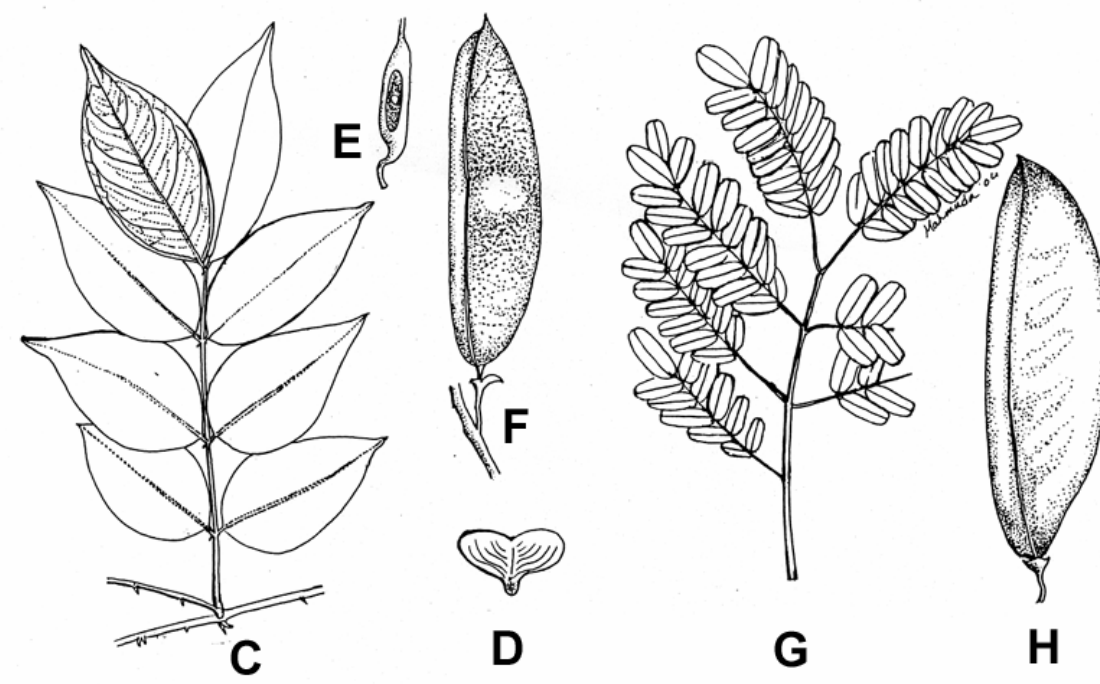

Plate 2. Caesalpinia crista (A-B): A. part of branch with leaves and pod $(\times 0.53)$; B. pod with seed after partly open $(\times 0.5)$. Caesalpinia cucullata $(\mathrm{C}-\mathrm{F})$ : C. part of rachis with pinnea $(\times 0.33)$; D. upper petal $(\times 1)$; E. ovary $(\times 2.67)$; F. pod with single seed $(\times 0.5)$. Caesalpinia enneaphylla $(\mathrm{G}-\mathrm{H})$ : $\mathrm{G}$. pinnea $(\times 0.83)$; H. pod with many seeds $(\times 0.5)$. 
Chromosome number: $2 \mathrm{n}=24$ (Atchison1951).

Ecology: In village thickets, along streams, river banks, mangrove forest and its fringes, coastal areas along seashore and on sandy beaches.

Specimens examined: Bagerhat: Mongla port area, 4.2.1987, Huq \& Mia, H 8182. Chittagong: Chakaria Sundarbans, 12.11.1979, Huq, Rahman \& Mia, H 4556. Cox's Bazar: Teknaf, St. Matin's Island, 29.1.1994, Yusuf, Huda, Dey, Hossain \& Emran, No. 4213; Teknaf, St. Martin's Island, 27.10. 1996, M.S. Khan, K. 9417.

Economic importance: The root is considered as diuretic. Roasted seeds, root and the juice of the stem are applied both externally and internally for treatment of eye diseases (Bor and Raizada 1954).

Ethnobotanical information: In India, the plant is used as the host of 'lac insect' and the finely powdered form of leaves is administered to women as a tonic just after delivery (Caius 1989).

Distribution: Archipelago, Australia, Cambodia, China, India, Malay Peninsula, Myanmar, Sri Lanka, Vietnam and Taiwan.

5. Caesalpinia cucullata Roxb., Fl. Ind. ed. 2 (2) : 358 (1832); Hattink, Reinwardtia 9 : 22 (1974); Mezoneuron cucullatum (Roxb.) Wight \& Arn., Prod. Fl. Pen. Ind. Or. : 283 (1834); Mezoneuron macrophyllum Bl. ex Miq., Fl. Ind. Bat. 1(1) : 104 (1855). M. cucullata var. grandis Heyne ex Baker, Fl. Brit. Ind. 2 : 258 (1878); M. cucullata var robusta Craib Fl. Siam. Enum. 1 : 499 (1928).

(Plate 2)

Local name: Bogaserra kanta

A large struggling, scandent, glabrous shrub. Leaves compound, exstipulate. Rachis c 12-30 cm long; pinnae 2-5 pairs, 7-15 cm long; leaflets 4-5 pairs, c 4.5-10.0 × 1.5-6.0 cm, opposite, ovate-elliptic, bluntly acuminate, rounded and somewhat unequal at base, shining above. Inflorescence of simple supra-axillary to terminal large panicles, c 15- 40 $\mathrm{cm}$ long, glabrous. Flowers bright yellow, bracteate, bract fugacious, very early caducous, pedicels $0.6-1.2 \mathrm{~cm}$ long, glabrous. Calyx up to $1 \mathrm{~cm}$ long, deeply divided, sepals 5, glabrous, lowest one hood-shaped and larger than the other 4 sepals. Petals 5, bright yellow, standard petals purplish-red, 2-lobed, butterfly shaped, c. 2.0-2.5 cm long, claw 6.0-7.5 mm long. Stamens 10; filaments short-hairy towards the base; anthers red. Ovary glabrous, 1-2 ovuled. Pods elliptic-lanceolate, c 8-12 × 2.5-3.5 cm, including papery wing about 4-6 mm wide along upper suture, reddish brown, 1 seeded at the middle of the pod. Seed orbicular, flat, c $1 \mathrm{~cm}$ across, shinning brown. Flowering and fruiting : January - September.

Chromosome number: $2 \mathrm{n}=22$ (Roy and Sinha 1966).

Ecology: In evergreen forests, along streams, near canals and on fringes. 
Specimens examined: Rajshahi : Nauhata, near a cannal, 7.2.1973, A.M. Huq, H 832; Rajshahi University Campus, 9.12.1972, A.M. Huq, H 515. Dinajpur : Thakurgoan, Kanthipur-Singra, 15.1.1974, Khan \& Huq, K 3599. Panchagar : Tetulia, Tirnai, 24.2.1984, Mia, Rahman \& Zaman, M 968. Sherpur : Jhenaigati, Gazni, 9.2.1985, M.S. Khan, K. 7052. Mymensingh : Madhupur forest, 28.2.1987, Huq, Mia \& Habib, H 8211.

Economic importance : Wood of this species is used as firewood.

Distribution: Bhutan, Cambodia, China, India, Indonesia, Malay Peninsula, Myanmar, Nepal, Nicabor Island, the Philippines, Thailand and Vietnam.

6. Caesalpinia decapetala (Roth) Alston in Trimen, Handb. Fl. Ceylon 6 (Suppl.): 89 (1931); Hattink, Reinwardtia 9: 24 (1974); Ali, Fl. Pak. 54: 31 (1973). Reichardia decapetala Roth, Nov. Pl. Spec. : 210 (1821); Caesalpinia ferrox Hassk., Fl. Java. Rar.: 400 (1848); C. sepiaria Roxb., Hort. Beng.: 32 (1814) nom nud. Fl. Ind. 2: 360 (1832); Baker in Hook. f., Fl. Brit. Ind. 2: 256 (1878).

(Plate 3)

Local names: Kander, Relan; English name: The Mysore thron

A scandent or scrambling shrub or small tree, up to $10 \mathrm{~m}$ tall. Leaves compound, bipinnate, up to $30 \mathrm{~cm}$ long, stipulate, stipules caducous. Rachis c 12- $24 \mathrm{~cm}$ long; pinnae 4-10 pairs; leaflets 8-12 pairs, opposite, sub-sessile, c 1.0-2.0 $\times$ 0.4-1.0 cm, oblong, obtuse, rounded at the apex, unequal at the base, glabrous above, sparsely pubescent beneath. Inflorescence of supra-axillary to terminal large racemes, c 20-30 cm long. Flowers bright yellow, c 1.2-1.8 cm long, often with red veins, bracts ovate lanceolate, pedicels c 2.0-3.0 cm. Calyx 1.0-1.3 cm long, fulvous hairy, 10 ribbed, sepals 5, golden hairy, the lowest sepal c 8-10 $\times 3-4 \mathrm{~mm}$, other 4 sepals c 6-8 $\times 3-4 \mathrm{~mm}$. Petals 5, suborbicular or obovate, standard petal c 1.3-1.4 cm long with 5-6 mm claw, the others up to $1.1 \mathrm{~cm}$ long, with 1-2 mm claw, obovate. Stamens 10, free; filaments $1.5 \mathrm{~cm}$ long, flattened and densely woolly at lower parts; anthers versatile. Pod oblong to falcateoblong, c 6.0-12.0 × 1.7-2.8 cm, flat, sharply beaked, dehiscent. Seeds 4-8 per pods, ellipsoid, dull black. Flowering and fruiting : May - September.

Chromosome number : 2n = 24 (Bir and Kumari 1973 as C. sepiaria).

Ecology : Sunny and dry habitats in bushy open places, in hedges and river banks.

Specimens examined: Kushtia : Chuadanga, Kalabari, 2.1.1976, Huq, Rahman \& Mia, H 1833; Chuadanga, A.M. Huq, H 4692.

Economic importance: The plant is medicinally important and different chemical products are obtained from this species (Kumar and Sane 2003). It is cultivated for excellent hedge plant and suitable for gardening for its bright yellow flowers in large racemes. The root is used as purgative. The plant is also used as the host of 'lac insect' (Ali 1973). 
Ethnobotanical information : In South India the bark of the plant is reported as a source of tanning material (Ali 1973). The tribal people of Naga in India use this plant as their village defense. The branches of the plant were erected on the forked poles over the paths during the day while at night the poles were removed and the plant laid on the ground as creeper, forming impenetrable barrier to any miscreant (Bor and Raizada 1954).

Distribution: Bhutan, China, Hong Kong, India, Indonesia, Japan, Korea, Laos, Malaysia, Myanmar, Nepal, Pakistan, Sri Lanka, Thailand and Vietnam.

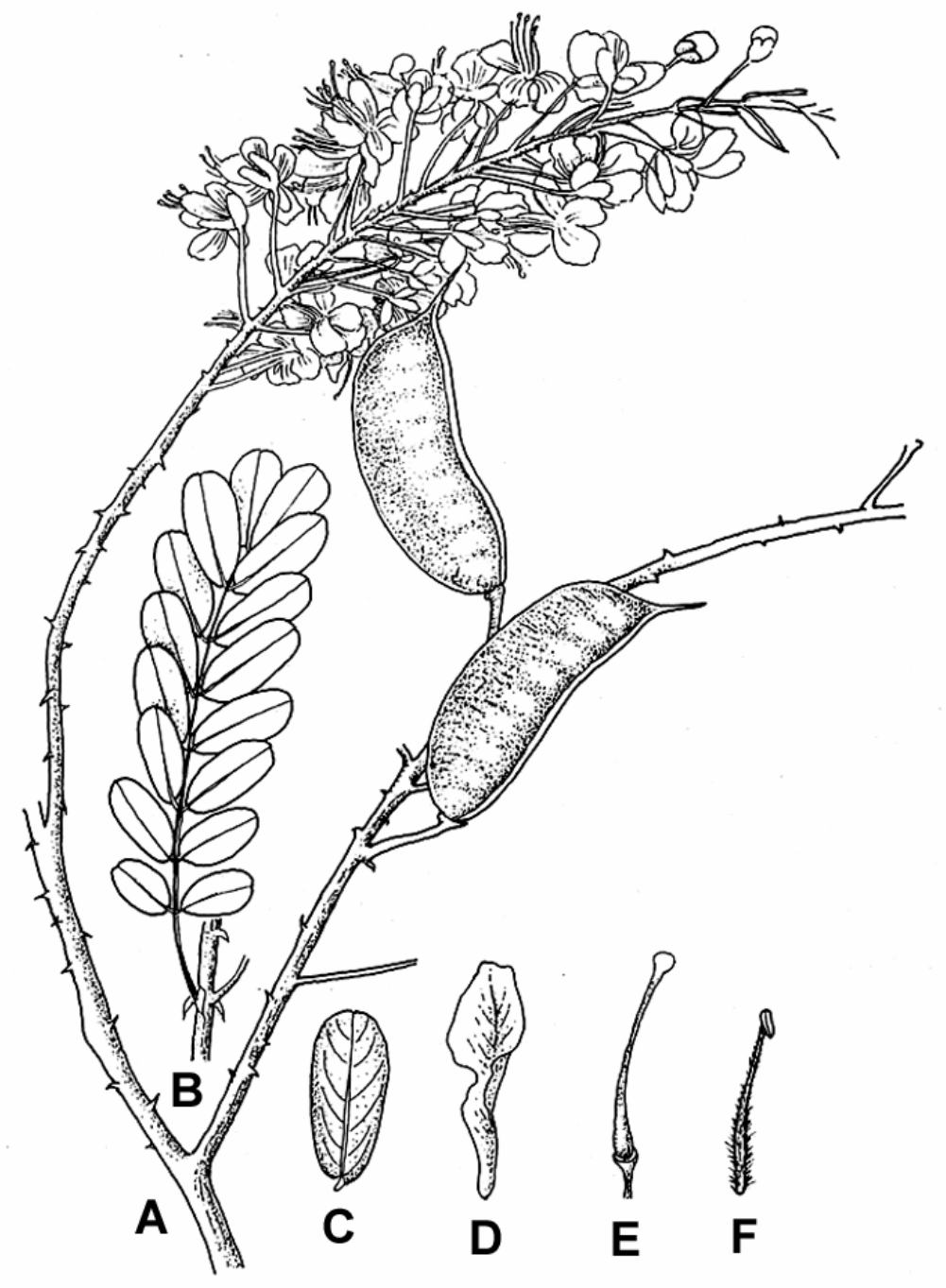

Plate 3. Caesalpinia decapetala (A-E): A. part of flowering branch with pods $(\times 0.67)$; B. part of rachis with pinna $(\times 1.33)$; C. leaflet $(\times 1.33)$; D. upper petal $(\times 1.67)$; E. pistil $(\times 1.67)$; F. stamen $(\times 1.33)$. 
7. Caesalpinia digyna Rottler, Ges. Naturf. Freunde. Berlin. Schrift. 4: 200, t. 3 (1803); Baker in Hook. f., Fl. Brit. Ind. 2: 256 (1878); Brandis, Ind. Trees: 247 (1906); Hattink, Reinwardtia 9: 28 (1974); Caesalpinia oleosperma Roxb., Fl. Ind. 2: 357 (1832).

Local names: Amalkuchi, Umulkuchi, Kochai, Teri

A large, struggling, scandent, prickly shrub or small tree with recurved prickles. Leaves compound, bipinnate, stipulate, stipules c $2 \mathrm{~mm}$ long, caducous. Rachis c 15-20 cm long, glabrous or sparsely pubescent; pinnae 6-12 pairs, up to $5 \mathrm{~cm}$ long; leaflets 8-12 pairs, opposite, sub-sessile, c 8-12 × 3-4 mm, oblong, obtuse to rounded, slightly unequal at base. Inflorescence supra-axillary to terminal panicles, c 16-30 cm long. Flowers bright yellow, c. 8-10 mm across, bracteate, bracts c $5 \mathrm{~mm}$ long, caducous, pedicels slender, c. 1.5-2.5 cm long. Sepals 5, oblong-obtuse, dotted, the lowest one hood-shaped, glabrous. Petals 5, obovate, oblong or orbicular, the standard petal constricted towards the middle, hairy inside. Stamens 10, free; filaments dilated at the base and densely woolly in lower part; anthers glabrous or with few hairs. Ovary glabrous or slightly hairy on the suture; style 6-8 mm long; stigma short-hairy along the margin. Pod elliptic-oblong, fleshy, c 4$6 \times 1.5-2.0 \mathrm{~cm}$, shortly beaked, indehiscent. Seeds $2-4$ per pod, sub-globose. Flowering and fruiting: July - January.

Ecology : In clearings, thickets, forest fringes, sometimes at the slop of the hills, and open and dry places.

Specimens examined: Chittagong : Fatikchari, Karnophuli Tea State area, 21.1.1989, Huq, Rahman \& Mahfuz, H 9012; Bariadhala to Hazarikhil, 14.10.1978, Khan \& Huq, K 5163; Dulhazara range, Harbang-Chakoria-Sunderbans, 21.11.1979, Huq, Rahman \& Mia, H 4555. Cox's Bazar : Teknaf range, Mochini beat, 7.10.1991, Khan, Huq, Mia \& Rahman, K 8630; Ukhia, Rezu range, 12.12.1985, Khan, Huq \& Mia, K 6855. Gazipur : Salna forest, 2.12.1980, Huq, Rahman, Mia, Mahbuba \& Momtaz, H 4856; Gori, 19.01.1969, Parvin A. Hashem, No. 31. Thakurgoan : Kantanagar, 15.1.1974, Khan \& Mia, K 3608.

Economic importance: The plant is important for chemical products, forage and medicine (Kumar and Sane 2003). The root is used for treatment of phthisis, scrofulous affections and diabetes (Caius 1989).

Ethnobotanical information: In some part of Myanmar, the pounded root is mixed with water to make a drink which is used as febrifuge (Caius 1989). The pods are considered as the source of tanning material (Kanjilal et al. 1938).

Distribution: Cambodia, China, India, Laos, Malaya Peninsula, Myanmar, Nepal, Sri Lanka, Thailand and Vietnam. 
8. Caesalpinia enneaphylla Roxb., Fl. Ind. ed. 2: 363 (1832); Hattink, Reinwardtia 9 : 30 (1974); Larsen et al., Fl. Thailand 4: 77 (1984); Mezonuron enneaphyllum (Roxb.) Wight \& Arn. ex Benth., Baker in Hook. f., Fl. Brit. Ind. 2: 258 (1878).

(Plate 2)

Local name : Kuchai

A woody climber armed with recurved prickles. Leaves compound, stipulate, stipules scale like. Rachis c 20-30 cm long; pinnae 8-12 pairs; leaflets 8-10 pairs, c 1.5-2.5 × 0.6$0.9 \mathrm{~cm}$, opposite, elliptic-oblong, obtuse, mucronate, retuse at apex, unequal at base. Inflorescence of axillary to terminal panicles, up to $30 \mathrm{~cm}$ long. Flowers pedicellate, pedicels c. 1.0-2.0 cm long, glabrous or sparsely hairy. Sepals 5, c 6-8 mm long, the lowest one hood-shaped, glabrous. Petals 5, bright yellow, the standard petal suborbicular with a claw protected into a glabrous, bilobed ligule. Stamens 10; filaments free, slightly larger than calyx; anthers glabrous. Ovary glabrous, 4-6 ovuled; style funnel-shaped; stigma shortly ciliate. Pod elliptic-oblong, c. 7.5-11.0 $\times$ 2.0-3.5 cm, including 4-6 mm wide dorsal wing, young pods red. Seeds 4-6, separated from each other. Flowering and fruiting : June - December.

Ecology : In dry hill slopes, secondary forests and open sunny places.

Specimens examined : Bandarban : Bandarban, 26.11.1983, Khan, Huq, Rahman \& Mia, K 6446; Chimbuk hills on way to Mirzapur, 27.11.1983, Khan, Huq, Rahman \& Mia, K 6520. Chittagong : Foyes lake, 24.01.1973, Khan \& Huq, K 2709; Chittagong University Campus, 3.12.1979, A.M. Huq, H 1655; Near Himchari Forest Office, 27.11.1970, Khan \& Huq, K 2299; Ukhia forest area, 29.12.1983, Mia, Huq \& Rahman, M 946. Sylhet : Jafflong, Sripur, 27.2.2000, Khan \& Mia, K 10285.

Economic importance : Cultivated as a garden plant.

Distribution : China, Malayan archipelago, Malaysia, Myanmar, Thailand and Vietnam.

9. Caesalpinia hymenocarpa (Prain) Hattink, Reinwardtia 9: 35 (1974) nov comb., Vidal, Fl. Camb. Laos \& Vietnam 18 : 46 (1980); Larsen \& Larsen, Fl. Malesiana Ser. 1, 12(2): 546 (1996); Mezoneuron hymenocarpum Prain, J. As. Soc. Beng. 66 (2): 472 (1897).

(Plate 4)

A much branched shrub to low tree. Leaves compound, stipulate, stipules c 0.5- 1.0 mm long. Rachis c 20-40 cm long, with recurved prickles in pairs; pinnae 6-8 pairs, pubescent; leaflets 10-18 pairs, c 1.2-2.5 $\times 0.6-1.5 \mathrm{~cm}$, obovate to obovate-oblong, rounded to emarginate at apex, unequal at base. Inflorescence of axillary to terminal large panicle, c 30-50 cm long. Flowers yellow, pedicillate, bracteate, bract triangular, c 5-6 $\mathrm{mm}$ long, pedicels c 8-15 mm long. Sepals 5, unequal, pubescent, the lowest one larger and hood-shaped, deeply cucullate, c 6.0-10.0 × 3.5-5.0 mm. Petals 5, yellow, standard petal orbicular or reniform, c 3-4 × 4-6 mm, with claw c 3-4 mm long, other petals with 
claw c 0.5-1.0 mm long. Stamens 10; filaments c 7-17 mm long, hairy at base; anthers 2.5 mm long, glabrous. Ovary 4-6 ovuled, glabrous; style c $12 \mathrm{~mm}$ long; stigma shortly ciliate. Pod elliptic-lanceolate, c 10.0-15.5 × 2.5- $3.5 \mathrm{~cm}$, with 7-12 mm wide dorsal wing, beaked, indehiscent, 3-6 seeded. Seeds ellipsoid, flat. Flowering and fruiting: July February.

Ecology : In secondary growth, hilly, monsoon forests, scrub jungles and river banks.

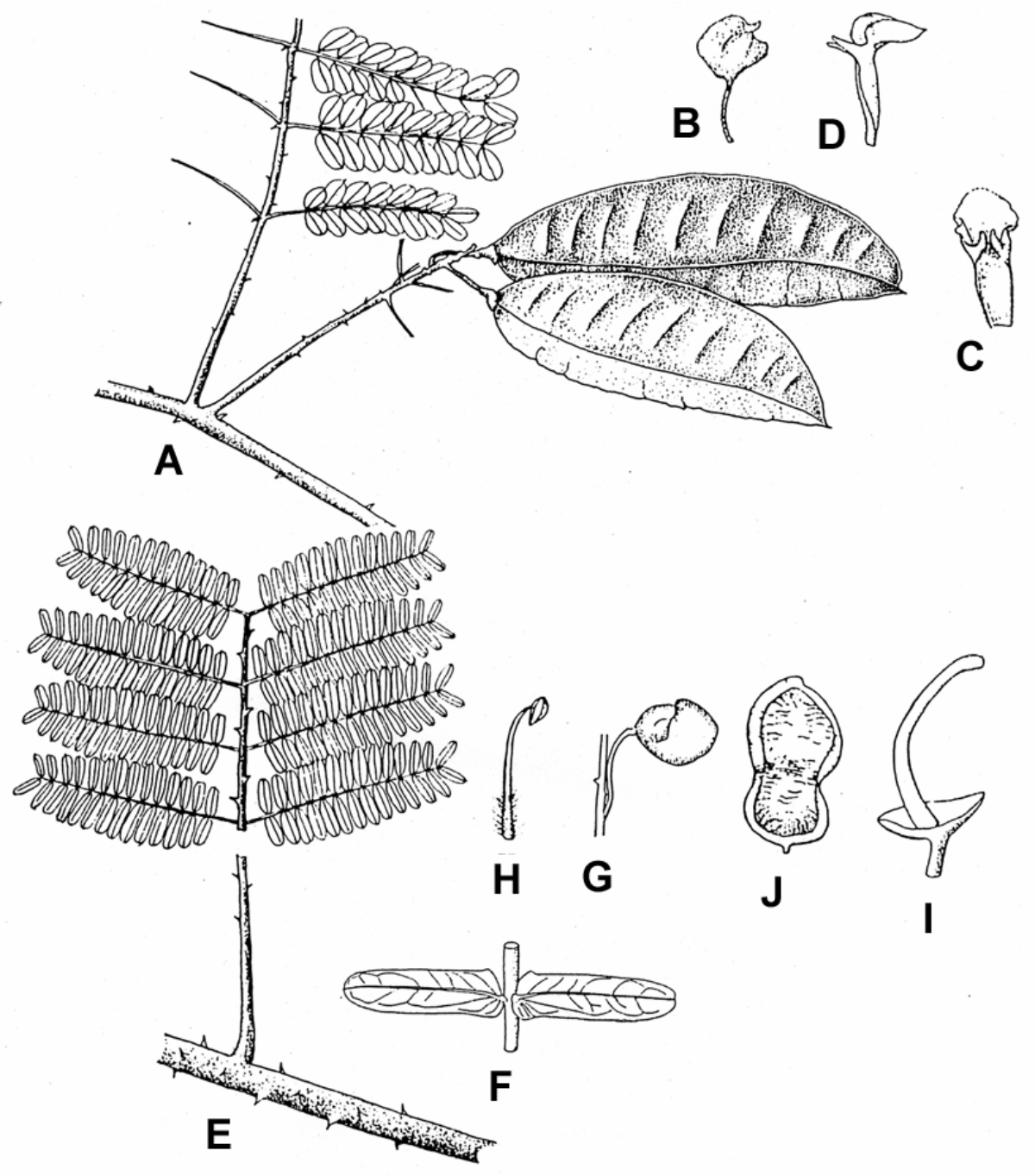

Plate 4. Caesalpinia hymenocarpa (A-D): A. part of branch with leaves and pods $(\times 0.5)$; B. flower bud $(\times 0.67)$; C. upper petal (front view) $(\times 0.67)$; D. upper petal (side view) $(\times 0.67)$. Caesalpinia tortuosa $($ E-J) E. part of branch with pinnae $(\times 0.5)$; F. a pair of leaflet $(\times 2)$; G. flower bud $(\times 1.33)$; H. stamen $(\times 1.33)$; I. pistil $(\times 2)$; J. pod $(\times 1)$. 
Specimens examined : Chittagong : Maheshkhali, 7.3.1987, Khan et al., K 4896; Foyes lake, 22.01.89, Momtaz \& Rezia, Mn. 79; Jaldi range, Sonai chari, 31.12.83. M.S. Khan, K 8212. Chittagong Hill Tracts : Mainimukh, Kalokchicha forest, 28.12.81, Huq, Rahman \& Mia, H 5458.

Economic importance : It is used as an ornamental and hedge plant.

Ethnobotanical information: The plant is used as the host of 'lac insects'and the bark is the source of tanning material in South India (Bor and Raizada 1954).

Distribution : Cambodia, China, India, Indonesia, Japan, Laos, Malaysia, Myanmar, Sri Lanka, Thailand and Vietnam.

10. Caesalpinia pulcherrima (L.) Swartz., Obs. Bot. Ind. Occ.: 166 (1791); Willd., Sp. Pl. 2: 531 (1799); Prain, Beng. Pl. 1: 449 (1903); Brandis, Ind. Trees: 247 (1906). Poinciana pulcherrima L., Sp. Pl.: 380 ( 1753); Baker in Hook, f., Fl. Brit. Ind. 2: 255 (1878).

Local names: Krisnachura, Radhachura, Chatta-Krisnachura; English names: Barbados Pride, Red Bird of Paradise

A handsome, much branched shrub to small tree, c 3-6 m tall. Leaves abruptly bipinnate, pinnately compound with stipules and stipels. Rachis c 10-40 cm long; pinnae 6-12 pairs, c 3-8 cm long; leaflets 5-13 pairs, c 0.5-2.5 $\times$ 0.4-1.5 cm, oblong-elliptic, rounded or emarginate, slightly mucronulate at apex. Inflorescence axillary to terminal large racemes, up to $40 \mathrm{~cm}$ long. Flowers orange-yellow, red to crimson-red or orangecrimson with yellow or cream margin, pedicels c 7.5-10.0 cm long. Sepals 4, free, c 0.7$1.5 \times 0.5-0.7 \mathrm{~cm}$, hooded, glabrous. Petals 5, free, 4 sub-equal, distinctly clawed, 5th petals with long clawed and smaller lamina, orbicular. Stamens 10, free; filament up to $7.5 \mathrm{~cm}$ long, very much long exserted; anthers versatile. Ovary seated on short gynophore, glabrous, compressed; style c 5.0-5.5 cm long; stigma ciliate. Pod oblong, compressed, c 5.0-8.5 × 1.5-2.0 cm, purple to dark brown, dehiscent. Seeds 8-10 per pod, brown or black. Flowering and Fruiting : Almost throughout the year but flowering profuse during February - April and September - November.

Chromosome number : 2n = 24 (Atchison 1951).

Ecology : Dry and sunny places, generally in gardens, parks and homesteads.

Specimens examined: Chittagong : Sitakund, Huq \& Mia, H 8052. Dhaka : Green Road, 18.03.1978, Huq et al., H 3878; Sahrawardy Uddan, 14.5.1980, Momtaz Begum 375. Mymensingh : Mymensingh, 2001, Sakir Hossain, No. 13; Sylhet : Jafflong, 20.10.1986, Huq \& Mia, H 7910.

Economic importance: It is planted as a popular ornamental plant. The leaves, flowers and seeds are largely used in Indian medicine. The pounded root is useful in 
infantile convulsions. The infusion of the flowers are used as a remedy of cough, chronic catarrh, asthma and malarial fever. Leaf juice is administered for treatment of fever (Bor and Raizada 1954). The fruits are main sources of tannin and the flowers yield a red dye (Chakraverty and Jain 1984).

Ethnobotanical information: In Indo-China, the plant is considered as tonic, stimulant and emmenagogue. In the Philippines, the leaves are used as purgative. An infusion of the flowers is used as febrifuge, and is applied for the treatment of bronchitis, asthma, and malarial fever (Caius 1989).

Distribution: Native of South America and cultivated throughout the tropics.

11. Caesalpinia sappan L., Sp. Pl.: 381 (1753); Kurz, For. Fl. Brit. Burma 1: 405 (1877); Backer in Hook f., Fl. Brit. Ind. 2: 255 (1878); Prain, J. As. Soc. Beng. 66 : 228 (1897); Hattink, Reinwardtia 9: 51 (1974); Larsen et al., Fl. Thailand 4: 65 (1984); C. minutiflora Elmer. Leaf. Philip. Bot. 5: 1803 (1913).

Local names: Bakam, Bakamkat, Patang

A prickly shrub or small tree of about $6 \mathrm{~m}$ high. Leaves compound, stipulate, stipules 3-4 mm long, caducous. Rachis $15-40$ cm long; pinnae $10-13$ pairs; leaflets $10-18$ pairs, c 1.0-2.0 $\times$ 0.6-1.0 cm, elliptic-oblong, sessile, very oblique at base, slightly emarginate at apex. Inflorescence of supra-axillary to terminal panicles, c. 30-40 cm long. Bract lanceolate, c $6 \mathrm{~mm}$ long, caducous, pedicels $1.5-2.0 \mathrm{~cm}$ long, pubescent. Flowers yellow, pubescent, calyx tube short, bowl shaped, sepals golden brown, hairy outside, glabrous inside, the lowest one more concave and larger. Petals 5, yellow, obovate, the standard petal smaller, constricted into a claw, hairy inside. Stamens exserted; filaments slightly longer than the petals, white, woolly in lower half; anthers glabrous. Ovary 3-6 ovuled, grey, velvety; style c $12 \mathrm{~mm}$ long; stigma ciliate. Pod obovate, obliquely oblong, 7.0-10.5 $\times$ 2.0-3.0 cm, flattened, woody, sessile on receptacle, widest toward the apex. Seeds ellipsoid, 3-4 per pod, dull black. Flowering and Fruiting : June - May.

Chromosome number : 2n = 24 (Ghose 1952).

Ecology: In scrub jungles, limestone hills and under cultivation around villages.

Specimens examined: Kushtia : Chuadanga, A.M. Huq, H 4592; Chuadanga, 2.1.1976, Huq, Rahman \& Mia, H 1833.

Economic importance : The species is important for wood, chemical products and medicine (Kumar and Sane 2003). The wood is used in decoction form in various diseases especially skin diseases (Caius 1989). It is also used as an ornamental plant.

Ethnobotanical information: Wood yields valuable dye to colour silk and starch red in holy occasion (Bor and Raizada 1954). In Indo-China, the decoction of wood is used 
as a powerful emmenagogue and used as vulnerary for wounds, hemorrhages and menstrual disorder. In China, it is used to cure dysentery and diarrhoea (Caius 1989).

Distribution : China, India, Indo-china, Malay Peninsula, Myanmar, New Guinea, Sri Lanka, and Taiwan.

12. Caesalpinia tortuosa Roxb., Fl. Ind. 2: 365 (1832); Baker in Hook. f., Fl. Brit. Ind. 2: 257 (1878); Hattink, Reinwardtia 9: 57 (1974); C. microphylla Buch.- Ham. ex Prain, J. Asiat. Soc. Beng. 66: 471 (1897); C. tortuosa Roxb. var grandiflora Fedde, Rep. Sp. Nov. 12: 39 (1913).

(Plate 4)

A climbing shrub to small tree up to $10 \mathrm{~m}$ high. Leaves pinnately compound, exstipulate. Rachis up to $60 \mathrm{~cm}$ long, often with recurved spines; pinnae 7-20 pairs, 6-15 cm long; leaflets 12-30 pairs, sessile, c 10-20 × 2-6 mm, narrowly linear-oblong, truncate at base, rounded to obtuse at apex, glabrous or sparsely puberulous beneath. Inflorescence of axillary to terminal or rarely supra-axillary panicles, c 20-60 cm long. Flowers bracteate, bract c $2 \times 1 \mathrm{~mm}$, pubescent. Sepals 5, c 8-10 × 4-6 mm, unequal, ciliate, lowest one deeply hooded. Petals 5 , unequal, standard petal orbicular, c $5 \mathrm{~mm}$ across with c 5-8 $\times 2 \mathrm{~mm}$ claw, hirsute above, other 4 petals orbicular to reniform, c 7-10 $\times$ 6-12 mm with 1-3 × $1 \mathrm{~mm}$ claw. Stamens 10 ; filaments $10-14 \mathrm{~mm}$ long, woolly at lower part, somewhat exserted; anthers c 2.5-3.0 × 0.7-1.0 mm. Ovary subsessile, hairy or glabrous; style 8-12 mm long, pubescent; stigma c $1 \mathrm{~mm}$ long. Pod elliptic-oblong, c 3.5$9.0 \times 2.0-3.5 \mathrm{~cm}$, obtuse, shortly beaked, turned black when dry, thickened at suture, indehiscent. Seeds 1-5 per pod, subglobose.

Specimen examined : No specimen was examined because of the non-availability, but this species was recorded from Sylhet district (Brandis 1906).

Ecology : Primary and secondary forests, forest margins and along rivers.

Economic importance: Wood is used as fuel.

Distribution: China, Hong Kong, India, Indonesia, Myanmar and Peninsular Malaysia. In Bangladesh this species was reported from Sylhet.

\section{Acknowledgement}

We thank Mr. Md. Ruhul Amin, Senior Artist-cum-Illustrator of Bangladesh National Herbarium for drawing some illustrations.

\section{References}

Ali, S.I. 1973. Caesalpiniaceae. In: Nasir, E. and Ali, S.I. (eds.) Flora of West Pakistan, No 54. Department of Botany, University of Karachi, West Pakistan, 47 pp.

Atchison, E. 1951. Studies in the Leguminosae. VI. Chromosome number among tropical woody species. Amer. J. Bot. 38(7): 538-547. 
Baker, J.G. 1878. Leguminosae. In: Hook. f., Fl. Brit. Ind. 2 : 254-257. Bishen Singh Mahendra Pal Singh, Dehra Dun, India.

Bir, S.S. and Kumari, S. 1973. In: IOPB chromosome number reports XLI. Taxon 22 : 459-464.

Bir, S.S. and Kumari, S. 1980. Cytological evolution of the Leguminous floras of the Punjab plains. Recent Research in Plant Science (ed. Bir, S.S.), Kalayani Publishers, Ludhiana, India, pp. 251-260.

Bor, N.L. and Raizada, M.B. 1954 (repr. ed.1982). Some Beautiful Indian Climbers and Shrubs. Bombay Natural History Society, pp. 60-72.

Brandis, D. 1906. Indian Trees. Bishen Singh Mahendra Pal Singh, Dhera Dun, India, pp. 245-247.

Caius, J.F. 1989. The Medicinal and Poisonous Legumes of India. Scientific Publisher, Jodhpur, India, pp. 1187.

Chakraverty, R.K. and Jain, S.K. 1984. Beautiful trees and shrubs of Calcutta. Botanical Survey of India, Howrah, Calcutta. p. 42.

Datta, R.B and Mitra, J.N. 1953. Common plants in and around Dacca city. Bull. Bot. Soc. Beng. 7(1\&2): 1110.

Ghani, A. 2002. Bheshaja Oshudh (Herbal Medicine). Bangla Academy, Dhaka. pp. 113-275.

Ghose, A.K. 1952. Chromosome numbers and meiotic behavior in two species of Caesalpinia. Sci. \& Cult. 17: 384-385.

Heinig, R.L. 1925. List of the plants of Chittagong Collectorate and Hill Tracts. Darjeeling, pp. 1-84.

Kanjilal, U.N., Kanjilal, P.C. and Das, A. 1938 (rep. ed.1982). Flora of Assam, Vol. 2. A Von Book Company, India, pp.1-176.

Kumar, K. and Sane, P.V. 2003. Legumes of South Asia (A check list). Royal Botanic Garden, Kew, 531 pp.

Khan, M.S., Khatun, B.M.R. and Rahman, M.M. 1996. A preliminary account of Legume diversity in Bangladesh. Bangladesh J. Plant Taxon. 3(1): 1-33.

Prain, D. 1903. Bengal Plants. Volume 1. Reprint edition 1963. pp. 322-323.

Roy, R.P. and Sinha, B.M.B. 1966. Cytological Studies in Mezuneuron cucullatum W. et A. Sci. \& Cult. 32 (9): 463-464.

Sanjappa, 1992. Legumes of India. Bishen Singh Mahendra Pal Singh. Dehra Dun India, pp. 9-14.

Sinclair, J. 1955. Flora of Cox's Bazar, East Pakistan, Bull. Bot. Soc. Beng. 9(2): 84-116.

Tribedi, G.N., Mugal, V. and Pal, D.C. 1993. Some less known ethnobotanical uses of plants in Sundarbans. Bull. Bot. Surv. Ind. 35(1-4): 6-10.

Verdcourt, B. 1979. A manual of New Guinea Legumes. Bulletin No. 11, Lae, Papua New Guinea, pp. 20-29. 